\title{
Professor J. A. F. Rook, CBE, DSc, FRSE, FRSC, FIBiol.
}

It is with a sense of real loss that ANIMAL PRODUCTION records the death, on 6 January 1987, of John Rook, the Senior Editor of this Journal from 1976 to 1984 , and one of its associate editors for four years prior to that. Scientific editing is a voluntary service to science and John Rook gave much to it despite his many other commitments and responsibilities which might have deterred another. John never expected less than the best from authors and when, inevitably, he did not always get it, his criticism was never carping but helpful and tinged, at least verbally, by his wry sense of humour. In fact, an abiding memory by his many friends and colleagues will be that sense of humour and the immense personal warmth of the man.

It is interesting that any quarrel he might have had with research in his editorial days was generally not with authors but with a system which, from time to time, allowed less than highly innovative and critical work to be undertaken - an outlook which he clearly carried through to his important rôle in the reorganization of the Agricultural and Food Research Council.

John Rook had a distinguished career in research, university teaching and science administration. His professional career started as an Agricultural Research Council post-graduate scholar at the (then) National Institute for Research in Dairying in Reading, followed by some years of research on the metabolism of ruminants at the Hannah Dairy Research Institute and at the National Institute for Research in Dairying. In 1965 he was appointed to the Chair of agricultural chemistry at Leeds University and in 1971 to the Directorship of the Hannah Research Institute at Ayr. Then, in 1981, he became second secretary of the Agricultural and Food Research Council in London. John Rook was also a past president of the British Society of Animal Production.

With his zeal for considering the strategy and not merely the tactics of agricultural research and development, it should have come as no surprise to his colleagues and associates of this journal that he should set about initiating, and steering through, major organizational changes in the conduct of agricultural research in the United Kingdom through his rôle in the Agricultural and Food Research Council. Whilst not everyone agreed with his cure, few would have denied his diagnosis of a need for change. Since the Agricultural Research Council was first founded, the agricultural industry, served by research, had changed almost beyond recognition and the nature of research had changed no less. Organizational change was inevitable but required both courage and vision to accomplish. John Rook was well possessed of both. It is sad that illness prevented him from enjoying retirement in his beloved native Yorkshire where he had returned not long before his death. He will be greatly missed by all his friends and colleagues. Our sympathy is extended to his wife and family. 